[4] Huikuri HV, Kervinen K, Niemelä M, et al. Effects of intracoronary injection of mononuclear bone marrow cells on left ventricular function, arrhythmia risk profile, and restenosis after thrombolytic therapy of acute myocardial infarction. Eur Heart J 2008;29:2723-32.

[5] Janssens S, Dubois C, Bogaert J, et al. Autologous bone marrow-derived stem-cell transfer in patients with ST-segment elevation myocardial infarction: doubleblind, randomised controlled trial. Lancet 2006;367:113-21.

[6] Li ZQ Zhang M, Jing YZ, et al. The clinical study of autologous peripheral blood stem cell transplantation by intracoronary infusion in patients with acute myocardial infarction (AMI). Int J Cardiol 2007;115:52-6.

[7] Kang HJ, Lee HY, Na SH, et al. Differential effect of intracoronary infusion of mobilized peripheral blood stem cells by granulocyte colony-stimulating factor on left ventricular function and remodeling in patients with acute myocardial infarction versus old myocardial infarction: the MAGIC Cell-3-DES randomized, controlled trial. Circulation 2006;114(1 Suppl):I145-51.

[8] Meluzín J, Mayer J, Groch L, et al. Autologous transplantation of mononuclear bone marrow cells in patients with acute myocardial infarction: the effect of the dose of transplanted cells on myocardial function. Am Heart J 2006;152 975.e9-15.

[9] Schächinger V, Assmus B, Erbs S, et al. Intracoronary infusion of bone marrowderived mononuclear cells abrogates adverse left ventricular remodelling postacute myocardial infarction: insights from the reinfusion of enriched progenitor cells and infarct remodelling in acute myocardial infarction (REPAIR-AMI) trial. Eur J Heart Fail 2009;11:973-9.

[10] Cochrane Handbook for Systematic Reviews of Interventions Version 5.1.0 (updated March 2011). In: Higgins JP, Green S, editors. The Cochrane Collaboration; 2011. Available from www.cochrane-handbook.org

[11] Egger M, Davey Smith G, Schneider M, Minder C. Bias in meta-analysis detected by a simple, graphical test. BMJ 1997;315:629-34.

[12] Duval S, Tweedie R. Trim and fill: a simple funnel-plot-based method of testing and adjusting for publication bias in meta-analysis. Biometrics 2000;56:455-63.
[13] Beitnes JO, Gjesdal O, Lunde K, et al. Left ventricular systolic and diastolic function improve after acute myocardial infarction treated with acute percutaneous coronary intervention, but are not influenced by intracoronary injection of autologous mononuclear bone marrow cells: a 3 year serial echocardiographic sub-study of the randomized-controlled ASTAMI study. Eur J Echocardiogr 2011;12:98-106.

[14] Piepoli MF, Vallisa D, Arbasi M, et al. Bone marrow cell transplantation improves cardiac, autonomic, and functional indexes in acute anterior myocardial infarction patients (Cardiac study). Eur J Heart Fail 2010;12:172-80.

[15] Castellani M, Colombo A, Giordano R, et al. The role of PET with $13 \mathrm{~N}$-ammonia and 18F-FDG in the assessment of myocardial perfusion and metabolism in patients with recent AMI and intracoronary stem cell injection. J Nucl Med 2010;51:1908-16.

[16] Grajek S, Popiel M, Gil L, et al. Influence of bone marrow stem cells on left ventricle perfusion and ejection fraction in patients with acute myocardial infarction of anterior wall: randomized clinical trial: Impact of bone marrow stem cell intracoronary infusion on improvement of microcirculation. Eur Heart J 2010;31:691-702.

[17] Nogueira FB, Silva SA, Haddad AF, et al. Systolic function of patients with myocardial infarction undergoing autologous bone marrow transplantation. Arq Bras Cardiol 2009;93(374-9):367-72.

[18] Plewka M, Krzemińska-Pakuła M, Lipiec P, et al. Effect of intracoronary injection of mononuclear bone marrow stem cells on left ventricular function in patients with acute myocardial infarction. Am J Cardiol 2009;104:1336-42.

[19] Wöhrle J, Merkle N, Mailänder V, et al. Results of intracoronary stem cell therapy after acute myocardial infarction. Am J Cardiol 2010;105:804-12.

[20] Traverse JH, McKenna DH, Harvey K, et al. Results of a phase 1, randomized double-blind, placebo-controlled trial of bone marrow mononuclear stem cell administration in patients following ST-elevation myocardial infarction. Am Heart J 2010;160:428-34.

\title{
Agreement between adjusted indirect comparison and simplified network meta-analyses on prasugrel and ticagrelor (Reply to Passaro et al. - Int J Cardiol 2011) is
}

\author{
Giuseppe Biondi-Zoccai ${ }^{\text {a,* }}$, Fabrizio D'Ascenzo ${ }^{\text {b }}$, Antonio Abbate ${ }^{c}$, \\ Pierfrancesco Agostoni ${ }^{\mathrm{d}}$, Maria Grazia Modena ${ }^{\mathrm{a}}$ \\ a Division of Cardiology, University of Modena and Reggio Emilia, Modena, Italy \\ ${ }^{\mathrm{b}}$ Division of Cardiology, University of Turin, Turin, Italy \\ c VCU Pauley Heart Center, Richmond, VA, USA \\ d Division of Cardiology, University Medical Center Utrecht, Utrecht, The Netherlands
}

\section{A R T I C L E I N F O}

\section{Article history:}

Received 22 May 2011

Accepted 6 June 2011

Available online 8 July 2011

\section{Keywords:}

Mixed treatment comparison

Meta-analysis

Network meta-analysis

Prasugrel

Systematic review

Ticagrelor

\footnotetext{
it Conflicts of interest: Dr. Biondi-Zoccai has lectured for Astra Zeneca, Bristol Myers Squibb, Sanofi-Aventis; he has consulted for Astra Zeneca and Eli Lilly.

* Corresponding author at: Division of Cardiology, University of Modena and Reggio Emilia, Via Del Pozzo 71, 41124 Modena, Italy. Tel.: + 3905942257 83; fax: + 39059 4223714

E-mail address: gbiondizoccai@gmail.com (G. Biondi-Zoccai).
}

We thank Passaro and colleagues for their interesting simplified network meta-analysis, [1] stemming from our recent adjusted indirect comparison meta-analysis comparing prasugrel versus ticagrelor in patients with acute coronary syndromes [2].

Indeed, network meta-analyses (i.e. mixed treatment comparisons) and adjusted indirect comparison meta-analysis are very closely related, as the latter may be considered a simplified network metaanalysis with a star shape [3]. Thus, the fact that Passaro et al. largely confirm the direction and magnitude of effect of our own analysis, thus supporting its precision, accuracy, and validity, comes a no major surprise, but rather testifies the consistency of these innovative statistical approaches (Table 1) [4]. We have already endeavored in this type of research study design in the past, focusing on first generation drug-eluting stents, $[5,6]$ second generation drug-eluting stents, [7] mechanical coronary recanalization after failed thrombolysis, [8] and antithrombotic agents for atrial fibrillation, [9] and so far none of our findings have been disproved by later trials or analyses.

The discrepancy reported by Passero et al. in comparison to our findings on the safety end-point of major bleeding (odds ratio 0.70 [95\% confidence interval $0.54-0.91$ ] in our work versus risk ratio 0.72 [0.50-1.04] in Passero et al.) might depend more on the definitions used than on the statistical method. Indeed, we employed the stringent albeit insensitive Thrombolysis in Myocardial Infarction 
Table 1

Comparison of statistical results from Biondi-Zoccai et al.'s adjusted indirect comparison meta-analysis [2] and Passero et al.'s network meta-analysis [1], both comparing prasugrel and ticagrelor in patients with acute coronary syndromes.*

\begin{tabular}{lll}
\hline End-point & $\begin{array}{l}\text { Biondi-Zoccai et al.'s } \\
\text { adjusted indirect } \\
\text { comparison } \\
\text { meta-analysis [2] }\end{array}$ & $\begin{array}{l}\text { Passero et al.'s } \\
\text { simplified } \\
\text { network } \\
\text { meta-analysis [1] }\end{array}$ \\
\hline $\begin{array}{ll}\text { Death, myocardial infarction } \\
\text { or stroke }\end{array}$ & $\mathrm{OR}=1.02(0.88-1.16)$ & $\mathrm{RR}=1.04(0.90-1.19)^{\dagger}$ \\
Death & $\mathrm{OR}=0.83(0.65-1.05)$ & $\mathrm{RR}=0.82(0.65-1.04)$ \\
Myocardial infarction & $\mathrm{OR}=1.12(0.94-1.33)$ & $\mathrm{NA}$ \\
Stroke & $\mathrm{OR}=1.18(0.75-1.81)$ & $\mathrm{NA}$ \\
Stent thrombosis & $\mathrm{OR}=1.59(1.08-2.32)$ & $\mathrm{NA}$ \\
Major bleeding & $\mathrm{OR}=0.70(0.54-0.91)$ & $\mathrm{RR}=0.72(0.50-1.04)$ \\
Major non-CABG-related bleeding & $\mathrm{OR}=0.95(0.69-1.32)$ & $\mathrm{NA}$ \\
Major CABG bleeding & $\mathrm{OR}=0.23(0.09-0.58)$ & $\mathrm{NA}$ \\
Major or minor bleeding & $\mathrm{OR}=0.79(0.65-0.96)$ & $\mathrm{NA}$ \\
Minor bleeding & $\mathrm{OR}=0.93(0.69-1.27)$ & $\mathrm{NA}$ \\
Drug discontinuation & $\mathrm{OR}=0.98(0.84-1.13)$ & $\mathrm{NA}$ \\
\hline
\end{tabular}

*Reported with $95 \%$ confidence intervals, with values $<1.0$ favoring ticagrelor, and $>1.0$ favoring prasugrel; ${ }^{\dagger}$ death from cardiovascular causes; $\mathrm{CABG}=$ coronary artery bypass grafting; $\mathrm{NA}=$ not available; $\mathrm{OR}=$ odds ratio; $\mathrm{RR}=$ risk ratio.

(TIMI) definition, and also distinguished coronary artery bypass grafting (CABG)-related major bleeding from non-CABG-related major bleeding [2]. Conversely, they did not specify which definition was chosen for their analysis, and moreover it is unclear whether they distinguished CABG-related from non-CABG-related major bleeding [1]. Thus, we cannot definitively address the purported discrepancy between their findings and our own for major bleeding.

They also appear to have overlooked other key end-points, including stent thrombosis, which remains in our opinion of utmost importance, and which appeared significantly less likely with prasugrel than with ticagrelor (odds ratio 0.63 [0.43-0.93], $\mathrm{p}=0.020$ in our work) [2]. In addition, we could not find details on the statistical methods used to build their analytical network nor the statistical package employed for computations. We guess they used Bayesian methods with non-informative priors and the WinBUGS package, [10] whereas we used fixed-effect frequentist methods and a freeware package developed by the Meta-analysis and Evidence based medicine Training in Cardiology (METCARDIO) group [11]. The aforementioned differences, as well as the simple impact of multiple testing and the use of risk ratios versus odds ratios might easily explain apparent discrepancies between the analyses.

In conclusion, we remain positive that advanced statistical approaches, including adjusted indirect comparison meta-analyses and mixed treatment comparisons, will play an ever increasing role in shaping clinical research and practice. Thus, this scholarly debate on our recent adjusted indirect comparison meta-analysis comparing prasugrel and ticagrelor in acute coronary syndromes is more than welcome and stands as further proof of the need for external repetition and validation of any research endeavor.

The authors of this manuscript have certified that they comply with the Principles of Ethical Publishing inthe International Journal of Cardiology (Shewan and Coats 2010;144:1-2).

\section{References}

[1] Passaro D, Fadda G, Maratea D, Messori A. Anti-platelet treatments in acute coronary syndrome: simplified network meta-analysis. Int J Cardiol 2011;150: 364-7.

[2] Biondi-Zoccai G, Lotrionte M, Agostoni P, et al. Adjusted indirect comparison metaanalysis of prasugrel versus ticagrelor for patients with acute coronary syndromes. Int J Cardiol 2011;150:325-31.

[3] Salanti G, Kavvoura FK, Ioannidis JP. Exploring the geometry of treatment networks. Ann Intern Med 2008;148:544-53.

[4] Biondi-Zoccai G, Landoni G, Modena MG. A journey into clinical evidence: from case reports to mixed treatment comparisons. HSR Proc Intensive Care Cardiovascular Anesth 2011;3:93-6.

[5] Biondi-Zoccai GG, Agostoni P, Abbate A, et al. Adjusted indirect comparison of intracoronary drug-eluting stents: evidence from a metaanalysis of randomized bare-metal-stent-controlled trials. Int J Cardiol 2005;100:119-23.

[6] Biondi-Zoccai GG, Lotrionte M, Abbate A, et al. Direct and indirect comparison meta-analysis demonstrates the superiority of sirolimus- versus paclitaxel-eluting stents across 5854 patients. Int J Cardiol 2007;114:104-5.

[7] Biondi-Zoccai G, Lotrionte M, Moretti C, et al. Percutaneous coronary intervention with everolimus-eluting stents (Xience V): systematic review and direct-indirect comparison meta-analyses with paclitaxel-eluting stents (Taxus) and sirolimuseluting stents (Cypher). Minerva Cardioangiol 2008;56:55-65.

[8] Testa L, van Gaal WJ, Biondi-Zoccai GG, et al. Repeat thrombolysis or conservative therapy vs. rescue percutaneous coronary intervention for failed thrombolysis: systematic review and meta-analysis. OJM 2008;101:387-95.

[9] Testa L, Zoccai GB, Porto I, et al. Adjusted indirect meta-analysis of aspirin plus warfarin at international normalized ratios 2 to 3 versus aspirin plus clopidogrel after acute coronary syndromes. Am J Cardiol 2007;99:1637-42.

[10] Fryback DG, Stout NK, Rosenberg MA. An elementary introduction to Bayesian computing using WinBUGS. Int J Technol Assess Health Care 2001;17:98-113.

[11] Meta-analysis and evidence based medicine Training in Cardiology (METCARDIO) indirect meta-analysis tool (ITC). Available from http://www.metcardio.org/ macros/IMT.xls last accessed on 21 May 2011. 